\title{
English summaries
}

\author{
Urban Violence and Networks of Solidarity \\ in Late Medieval France
}

Cl. Gauvard

During the XIVth and XVth centuries, when the French realm was still dominated by a network of small cities, and where conflictual relationships were codified by laws of honor, violence acted as a link between the city and its environs. The majority of crimes committed were homicides or slander charges resulting from conflicts. Since the city was the site of dense social networks, it became the stage upon which one's good name could be cleared, even when the protagonists were not city-dwellers. In the latter case, people from the countryside came to the city to seek public justice within a district pertinent to their worldview. Within the city itself, even in the large cities, a sense of honor was still intact. Neighbours thus had an important role in defining each others' reputation, and they could take over the role implementing royal orders, especially when moral issues were involved. In this sense the city was less afraid of professional criminals-who remained in the minority - than of outsiders, who often became scapegoats. Violence was thus not a pertinent criterion for defining medieval urban identity.

\author{
Fraternities, Solidarity and Social Change \\ in the Late-Medieval English Town
}

G. ROSSER

This essay makes a direct link between the demographic and social change of the late Middle Ages and the contemporary proliferation of fraternities in England. The particular prominence of fraternities in towns is emphasised, as is the fact that membership offered to the recent immigrant both a surrogate family to replace the one left behind, and an opportunity for integration within urban society. The fraternities offered support in a variety of ways, including welfare provision, financial loans, and an opportunity to secure the patronage of the powerful. In addition, they undertook ritual and spiritual roles within their communities which lent prestige to their memberships. Their political potential is also discussed, in connection with those fraternities which came effectively to govern a number of small towns in this period. The fraternities should not be romanticised. But it is argued that both as a means of providing practical assistance and a dignified identity to a growing and vulnerable class of middling townspeople, and as a forum for the articulation of relations between different social groups in the late-medieval town, the fraternities played a dynamic role. 
The author questions the theoretical status of social sciences through a partial assessment of one of them, social anthropology. Discipline linked to the colonial expansion of european societies and to their domination over the rest of the world, but associated also with the need of the Nation-State of Europe to deal with peasant and ethnical local customs resisting to economic and political transformations, social anthropology is deeply rooted into the history and domination of Europe. However, the discipline achieved its first scientific results only when it could construct its concepts and analysis beyond and against the social representations and concepts dominating European culture. This contradiction was present since the beginning as illustrated by the work of Lewis H. Morgan, its founder, who opened the vast field of research on kinship, domain par excellence of the ethnologists. Morgan discovered that all the kinship systems known in his time, included the European ones, were variants of seven basic types never identified before him. But soon he used his remarquable discoveries in order to build up an outline of the evolution of mankind in which these forms of kinship succeeded each other in an order moving from primitive savagery to Anglo-Saxon modern civilization. The West was again the mirror and the measure of the development of mankind. Anthropology after Morgan was obliged to break with this evolutionism. So, where are we after one century of researches on kinship? Is kinship based mainly on principles of descent, as stated by Meyer Fortes, or on principles of alliance and marriage, as argue Levi-Strauss and Dumont? Does alliance imply necessarily exchange of women between men and universal male domination? Are classificatory kinship systems mere extensions of intrafamily relationships? Has the concept of consanguinity still a universal value? What are the relationships between kinship systems and economic or political systems? At the end of this critical assessment it seems clear that anthropology, far from being a discipline in deep crisis and close to disappear, is well alive and still for a long time indispensable.

\section{Individual in Middle Age. A Case Study: Opicinus de Canistris}

A. Gourevitch

Autobiographical drawings accompanied by texts produced by an Italian cleric Opicinus de Canistris (the first half of the XIVth century) shed a new ligth onto the structure of human personality of the Late Middle Ages. The inverted relationship between "microcosm" and "megacosm", displayed in the fact that the person of Opicinus absorbs the entire Europe and Mediterranean, as well as his megalomania (Opicinus insists that he is responsible for the sins of the mankind) testify to the destruction of the traditional world-view. Pictorial means of self-expression gave the cleric (who seems to be mentally unbalanced) more freedom to reveal his psychology than it was possible to his great contemporaries Dante and Petrarch.

\section{Medical Knowledge and Religious Anthropology: Representations of vetula (XIIIth-XVth Century)}

\section{J. Agrimi and Ch. CRisciani}

Our aim in this essay is to explore the changing image of the vetula in the late Middle Ages. Initially, in the first phase of the period we have surveyed, the role and power of the vetula-as the emblem of simplices, empirici, mulieres - are represented as two-edged. According to Roger Bacon, for instance, although secreta sapientiae 
can be bestowed upon her by God, she is liable to be misled by the Devil. Subsequently, a negative connotation of this figure prevails (e. $g$. the "vieille sorcière" described by Jean Gerson). In our view, this representation could provide the background-a sort of collection of features-on which the image of the witch was constructed later (e. g. the strix of Gianfrancesco Pico della Mirandola). We examined medical, philosophical, theological, pastoral texts of the Thirteenth to the Fifteenth Centuries. Our approach to this process develops along an intermediate course between researches on demonological theories and those on inquisitorial practices-and the sources we examine reflect this choice.

Fiction in the Archives? the Monster of 1569

D. CRESSY

In 1569 Agnes Bowker, a servant in Leicestershire, England, allegedly gave birth to a cat. Ecclesiastical and secular officials struggled to understand whether this bestial monstrous birth really happened, or whether it masked some other witchedness such as infanticide or sorcery. The seriousness of their enquiry was heightened by the political, religious and cultural uncertainties of early Elizabethan England. The documentation in this case, including abundant testimony from the midwife, male and female neighbours, and Agnes herself, touches on a broad range of issues: normal and abnormal childbirth; gender relations and sexuality; diabolism and seduction; monstrosity and imagination; the proceedings of community discourse and ecclesiastical. 